\title{
Practical approach for paving the way to motivate BIM non-users to adopt BIM
}

\author{
Ashraf Elhendawi ${ }^{1 *}$, Hany Omar ${ }^{2}$, Emad Elbeltagi ${ }^{3}$, Andrew Smith $^{4}$
}

\begin{abstract}
Typically, the Architecture, Engineering, and Construction (AEC) industry is considered one of the most effective contributor to the national developments worldwide. However, the AEC industry is facing myriad challenges due to the pressing calls for creativity and innovative solutions. Several issues are confronted such as failure to meet client satisfaction, delays in delivering projects on time, cost overruns, low quality, conflicts among parties, safety issues, increasing requests for change orders, tremendous increases in materials waste and project complexity. Building Information Modeling (BIM) is rapidly growing worldwide as a viable tool for improving the efficiency of the AEC industry to solve its salient issues. However, BIM is seldom adopted on the government level, especially in the developing countries. This study aims to explore the stakeholders' perceptions on the benefits of BIM and the barriers that hindered its adoption. Furthermore, practical solutions to motivate BIM non-users to adopt BIM are proposed. A questionnaire was sent to BIM users and non-users in the Kingdom of Saudi Arabia (KSA) as a case study. The key findings that deterred the implementation of BIM were personal correlated issues such as resistance to change and lack of appropriate awareness of BIM. This study convenes the industry players concerning BIM benefits and reveals the barriers and their potential solutions to encourage them to reap the benefits form BIM adoption.
\end{abstract}

Keywords: BIM barriers, benefits, BIM implementation, AEC, KSA, top management.

\section{Introduction:}

The AEC industry is considered as the backbone of the economy for several countries worldwide (Elhendawi, et al., 2019). Consequently, the construction industry has substantial impacts on the growth of nations (Giang \& Pheng, 2011). For decades, the AEC industry has been suffering from a plethora of problems and lags behind other industries. Client requirements tend not to be achieved, with projects delivered beyond schedule, over budget and with low quality (Ahmed, et al., 2018). AEC is suffering from low productivity, poor efficiency, ineffective performance, low support to sustainability (Azhar, et al., 2015), insufficient environment protection, poor working conditions and loss of control on safety (Latiffi, et al., 2013).

Recently, the construction industry has become more complex to manage (Omar \& Dulaimi, 2015). This is due to technical complexity, various data to be managed, continuous changes in the supply chain management systems, contractual provision (Ahmed, et al., 2018), and the pressing demands for smart and green buildings (Marzouk, et al., 2014). As such, several researchers have considered BIM as a

\footnotetext{
1 MSc., PMP. School of Engineering and the Built Environment, Edinburgh Napier University, UK

* Corresponding author. E-mail address: ashrafnasr86al@yahoo.com

2 Department of Architecture and the Built Environment, Faculty of Environment and Technology, University of the West of England, UK

3 Ph.D., P.Eng. Professor of Construction Management, Structural Engineering Department, Mansoura University, Egypt

4 Ph.D. School of Engineering and the Built Environment, Edinburgh Napier University, UK
} 
panacea to enhance communication and collaboration among the AEC industry key players (Gerges, M, et al. ،2017 ؛Matarneh \& Hamed ،2017).

The roots of BIM can be traced back to the 1970s. However, the AEC industry commenced use of BIM in the 2000s. Since then, several companies and governments have recognised the benefits of BIM and accordingly have adopted BIM (Eastman, et al., 2011).

This study aims to address the main advantages and barriers for BIM users and non-users and to suggest practical solutions that pave the way to overcome the barriers and enhance the chances to reap the utmost benefits of BIM. To that end, an extensive literature review was conducted to grasp the stateof-the-art pertaining to benefits and obstacles experienced by BIM users and non-users.

\section{Literature Review:}

Currently, BIM has shown its competency to improve AEC industry performance and enhance collaboration among various project parties. BIM is considered a revolutionary technology and process management proposed as a potential solution to the current salient issues in the AEC industry (Azhar, et al., 2015; Love, et al., 2014). BIM was suggested as a tool to support the pre-design phase (Ham, et al., 2008), visualisation interference and clash detection, construction sequencing, cost estimation, fabrication/shop drawings, automated fabrication, code reviews, and data analysis (Forbes \& Ahmed, 2011). It also supports construction planning, constructability and analysis, cost and quantity take-off (Autodesk Design Academy, 2017), enterprise resource planning (Elbeltagi \& Dawood, 2011), Virtual Reality (VR) (Omar, 2015), Facility Management (FM) (Elhendawi, et al., 2019), project management (Ahmed, et al., 2018) and Augmented Reality (AR) for interactive visualisation (Wang, et al., 2014). Furthermore, construction management education can benefit (Abbas, et al., 2016) as well as health and safety (Ganah \& John, 2015), Integrated Project Delivery (IPD) (Glick \& Guggemos, 2009), Geography Information System (GIS) (Baik, et al., 2015), Green Building (Marzouk, et al., 2014; Amor, et al., 214) and Lean construction (Zewein, 2017).

As per its perceived benefits, many developed countries such as Canada, UK, Finland, Singapore, Norway, Denmark, South Korea, Australia, Hong Kong and the Netherlands have mandated BIM in their public AEC industry projects, while others have adopted future plans for mandating BIM (Lee, et al., 2014). However, almost all developing countries have not mandated BIM yet (Elhendawi, et al., 2019). From the Gulf Cooperation Council (GCC) members in 2014, only Dubai municipality had mandated BIM in some of its selected large projects.

\subsection{The benefits of BIM}

The AEC industry, like other industries, benefits from Information and Communication Technology (ICT). Features of BIM could be predestined in different ways depending on how far users have experienced either beginners or experts (McGraw-Hill, 2009). Based on an extensive literature review, Table (1) summarises the most recognised benefits of BIM and the beneficiary party. 
Dec - 2019; Volume: 2 Issue: 2 page: 01-22

Table 1: Perceived benefits of BIM from literature

\begin{tabular}{|c|c|c|c|c|c|c|c|c|}
\hline \multirow{2}{*}{ No. } & \multirow{2}{*}{ Benefits of BIM } & \multicolumn{6}{|c|}{ Stakeholders } & \multirow{2}{*}{ Authors } \\
\hline & & $\mathrm{C}^{*}$ & $\mathrm{~A} / \mathrm{E}^{*}$ & $\mathrm{C} / \mathrm{SC}^{*}$ & $\mathrm{~S}^{*}$ & OS* & $\mathrm{FM}^{*}$ & \\
\hline 1 & $\begin{array}{l}\text { Time saving (reduces the time spent on } \\
\text { project documentation, communication, } \\
\text { and comparing among different options } \\
\text { in a very short time) }\end{array}$ & $\sqrt{ }$ & $\sqrt{ }$ & $\sqrt{ }$ & $x$ & $\sqrt{ }$ & $x$ & $\begin{array}{l}\text { (Chan, 2014; } \\
\text { Doumbouya, et al., } \\
\text { 2016; Matarneh \& } \\
\text { Hamed, 2017) }\end{array}$ \\
\hline 2 & $\begin{array}{l}\text { Cost reduction (lowers projects whole } \\
\text { cost, design and construction costs, } \\
\text { reduced communication cost) }\end{array}$ & $\sqrt{ }$ & $\sqrt{ }$ & $\sqrt{ }$ & $x$ & $\checkmark$ & $x$ & $\begin{array}{l}\text { (Doumbouya, et al., } \\
\text { 2016; Matarneh \& } \\
\text { Hamed, 2017) }\end{array}$ \\
\hline 3 & Improved budget and cost estimation & $\sqrt{ }$ & $\checkmark$ & $\checkmark$ & $x$ & $\checkmark$ & $x$ & $\begin{array}{l}\text { (Elhendawi, et al., } \\
\text { 2019) }\end{array}$ \\
\hline 4 & $\begin{array}{l}\text { Improving quality (reduced rework, and } \\
\text { better design) }\end{array}$ & $\sqrt{ }$ & ป & $\checkmark$ & $\sqrt{ }$ & $\sqrt{ }$ & $\sqrt{ }$ & $\begin{array}{l}\text { (Gerges, M, et al., } \\
\text { 2017) }\end{array}$ \\
\hline 5 & $\begin{array}{l}\text { Quick and right decisions based on } \\
\text { authenticated data }\end{array}$ & $\checkmark$ & $\sqrt{ }$ & $\sqrt{ }$ & $\sqrt{ }$ & $\sqrt{ }$ & $\sqrt{ }$ & $\begin{array}{l}\text { (Harrison \& Thurnell, } \\
\text { 2014; Love, et al., } \\
\text { 2014) }\end{array}$ \\
\hline 6 & $\begin{array}{l}\text { Clash detection (check design non- } \\
\text { conformities during pre-construction } \\
\text { stage, resolve conflicts for different } \\
\text { disciplines ahead of construction) }\end{array}$ & $\checkmark$ & $\sqrt{ }$ & $\sqrt{ }$ & $\sqrt{ }$ & $\checkmark$ & $\sqrt{ }$ & $\begin{array}{l}\text { (Matarneh \& Hamed, } \\
\text { 2017; Gerges, M, et } \\
\text { al., 2017) }\end{array}$ \\
\hline 7 & $\begin{array}{l}\text { Improve visualization (simulation, } \\
\text { representation of the building in an } \\
\text { integrated data environment, eliminating } \\
\text { the risk of misinterpretation of design) }\end{array}$ & $\sqrt{ }$ & $\checkmark$ & $\sqrt{ }$ & $\sqrt{ }$ & $\checkmark$ & $\sqrt{ }$ & $\begin{array}{l}\text { (Autodesk, 2015; } \\
\text { Gerges, M, et al., } \\
\text { 2017; Shaban \& } \\
\text { Elhendawi, 2018) }\end{array}$ \\
\hline 8 & $\begin{array}{l}\text { Enhance collaboration and } \\
\text { communication between all parties } \\
\text { (simultaneous work by multiple } \\
\text { disciplines) }\end{array}$ & $\sqrt{ }$ & $\sqrt{ }$ & $\sqrt{ }$ & $\sqrt{ }$ & $\checkmark$ & $\checkmark$ & $\begin{array}{l}\text { (Autodesk, 2015; } \\
\text { Matarneh \& Hamed, } \\
\text { 2017; Ahmed, et al., } \\
\text { 2018) }\end{array}$ \\
\hline 9 & $\begin{array}{l}\text { Maintain control through the entire } \\
\text { project life cycle }\end{array}$ & $\sqrt{ }$ & $\checkmark$ & $\sqrt{ }$ & $\sqrt{ }$ & $\sqrt{ }$ & $\sqrt{ }$ & $\begin{array}{l}\text { (Matarneh \& Hamed, } \\
\text { 2017) }\end{array}$ \\
\hline 10 & Reduce risks & $\sqrt{ }$ & $\sqrt{ }$ & $\sqrt{ }$ & $\sqrt{ }$ & $\sqrt{ }$ & $\sqrt{ }$ & (Jernigan, 2014) \\
\hline 11 & $\begin{array}{l}\text { Support construction and project } \\
\text { management (executive, } \\
\text { communication, strategic planning, site } \\
\text { planning, risk management, change } \\
\text { plans, improved safety, added value, and } \\
\text { better facility management) }\end{array}$ & $\sqrt{ }$ & $\sqrt{ }$ & $\checkmark$ & $\sqrt{ }$ & $\checkmark$ & $\sqrt{ }$ & $\begin{array}{l}\text { (Latiffi, et al., 2013; } \\
\text { Chan, 2014; Gerges, et } \\
\text { al., 2016; Matarneh \& } \\
\text { Hamed, 2017) }\end{array}$ \\
\hline 12 & $\begin{array}{l}\text { Reduce accidents by promoting safety } \\
\text { plans }\end{array}$ & $\sqrt{ }$ & $x$ & $\sqrt{ }$ & $x$ & $\checkmark$ & $x$ & (Moreno, et al., 2013) \\
\hline 13 & Error-free design & $\sqrt{ }$ & $\sqrt{ }$ & $\sqrt{ }$ & $\sqrt{ }$ & $\sqrt{ }$ & $\sqrt{ }$ & (Almutiri, 2016) \\
\hline 14 & $\begin{array}{l}\text { Reduced requests for information } \\
\text { (RFIs') (promote project understanding } \\
\text { and eradicates any ambiguity) }\end{array}$ & $\sqrt{ }$ & $\sqrt{ }$ & $\sqrt{ }$ & $\sqrt{ }$ & $\sqrt{ }$ & $\sqrt{ }$ & $\begin{array}{l}\text { (Azhar, et al., 2011; } \\
\text { Abbasnejad \& Moud, } \\
\text { 2013) }\end{array}$ \\
\hline 15 & Early involvement for client & $\sqrt{ }$ & $\checkmark$ & $\checkmark$ & $\sqrt{ }$ & $\checkmark$ & $\sqrt{ }$ & $\begin{array}{l}\text { (Jernigan, 2014; } \\
\text { Omar, 2015) }\end{array}$ \\
\hline 16 & $\begin{array}{l}\text { Promote the client and customer } \\
\text { satisfaction }\end{array}$ & $\sqrt{ }$ & $\checkmark$ & $\checkmark$ & $\sqrt{ }$ & $\checkmark$ & $\checkmark$ & (Karna, et al., 2009) \\
\hline 17 & $\begin{array}{l}\text { Keep stakeholders informed and } \\
\text { satisfied }\end{array}$ & $\sqrt{ }$ & $\sqrt{ }$ & $\sqrt{ }$ & $\sqrt{ }$ & $\checkmark$ & $\sqrt{ }$ & (Jernigan, 2014) \\
\hline 18 & Maximising productivity & $\sqrt{ }$ & $\checkmark$ & $\sqrt{ }$ & $\sqrt{ }$ & $\checkmark$ & $\checkmark$ & $\begin{array}{l}\text { (Matarneh \& Hamed, } \\
\text { 2017) }\end{array}$ \\
\hline
\end{tabular}


Dec - 2019; Volume: 2 Issue: 2 page: 01-22

\begin{tabular}{|c|c|c|c|c|c|c|c|c|}
\hline 19 & $\begin{array}{l}\text { Availability of data throughout the } \\
\text { project lifecycle }\end{array}$ & $\sqrt{ }$ & $\sqrt{ }$ & $\sqrt{ }$ & $\sqrt{ }$ & $\sqrt{ }$ & $\sqrt{ }$ & $\begin{array}{l}\text { (Gerges, M, et al., } \\
\text { 2017) }\end{array}$ \\
\hline 20 & $\begin{array}{l}\text { Reduced Document Errors and } \\
\text { omissions }\end{array}$ & $\sqrt{ }$ & $\sqrt{ }$ & $\sqrt{ }$ & $\sqrt{ }$ & $\sqrt{ }$ & $\sqrt{ }$ & (Autodesk, 2015) \\
\hline 21 & $\begin{array}{l}\text { Minimising changes (significantly } \\
\text { reduce change orders) }\end{array}$ & $\sqrt{ }$ & $\sqrt{ }$ & $\sqrt{ }$ & $\sqrt{ }$ & $\sqrt{ }$ & $x$ & $\begin{array}{l}\text { (Matarneh \& Hamed, } \\
\text { 2017) }\end{array}$ \\
\hline 22 & Enhance site logistic plans & $\sqrt{ }$ & $x$ & $\sqrt{ }$ & $\sqrt{ }$ & $\sqrt{ }$ & $\sqrt{ }$ & (Saleh, 2015) \\
\hline 23 & $\begin{array}{l}\text { Enhance lean construction principle and } \\
\text { value engineering }\end{array}$ & $\sqrt{ }$ & $\sqrt{ }$ & $\sqrt{ }$ & $\sqrt{ }$ & $\sqrt{ }$ & $\sqrt{ }$ & $\begin{array}{l}\text { (Zewein, 2017; Khalil, } \\
\text { 2017) }\end{array}$ \\
\hline 24 & Promote value for money & $\sqrt{ }$ & $\sqrt{ }$ & $\sqrt{ }$ & $\sqrt{ }$ & $\sqrt{ }$ & $\sqrt{ }$ & $\begin{array}{l}\text { (Elmualim \& Gilder, } \\
\text { 2014) }\end{array}$ \\
\hline 25 & $\begin{array}{l}\text { Increase efficiency (faster and more } \\
\text { effective processes and methods) }\end{array}$ & $\sqrt{ }$ & $\sqrt{ }$ & $\sqrt{ }$ & $\sqrt{ }$ & $\sqrt{ }$ & $\sqrt{ }$ & $\begin{array}{l}\text { (Doumbouya, et al., } \\
\text { 2016; Matarneh \& } \\
\text { Hamed, 2017) }\end{array}$ \\
\hline 26 & Improve building sustainability analyses & $\sqrt{ }$ & $\sqrt{ }$ & $\sqrt{ }$ & $\sqrt{ }$ & $\sqrt{ }$ & $\sqrt{ }$ & $\begin{array}{l}\text { (Eadie, et al., 2013; } \\
\text { Doumbouya, et al., } \\
\text { 2016) }\end{array}$ \\
\hline 27 & Creative and innovative solutions & $\sqrt{ }$ & $\sqrt{ }$ & $\sqrt{ }$ & $\sqrt{ }$ & $\sqrt{ }$ & $\sqrt{ }$ & $\begin{array}{l}\text { (Azhar, 2011; Chan, } \\
\text { 2014) }\end{array}$ \\
\hline 28 & Automated assembly & $\sqrt{ }$ & $x$ & $\sqrt{ }$ & $\sqrt{ }$ & $\sqrt{ }$ & $\sqrt{ }$ & (Azhar, et al., 2015) \\
\hline 29 & $\begin{array}{l}\text { Reduce waste (the elimination of waste } \\
\text { and value generation) }\end{array}$ & $\sqrt{ }$ & $\sqrt{ }$ & $\sqrt{ }$ & $\sqrt{ }$ & $\sqrt{ }$ & $\sqrt{ }$ & $\begin{array}{l}\text { (Omar \& Dulaimi, } \\
\text { 2015; Autodesk, 2015) }\end{array}$ \\
\hline 30 & $\begin{array}{l}\text { Enhance competitiveness (promote the } \\
\text { company's competitive advantages) }\end{array}$ & $\sqrt{ }$ & $\sqrt{ }$ & $\sqrt{ }$ & $\sqrt{ }$ & $\sqrt{ }$ & $\sqrt{ }$ & $\begin{array}{l}\text { (National Building } \\
\text { Specification, 2014; } \\
\text { Azhar, et al., 2015) }\end{array}$ \\
\hline 31 & $\begin{array}{l}\text { Facility management (during } \\
\text { preconstruction and construction) }\end{array}$ & $\sqrt{ }$ & $\sqrt{ }$ & $\sqrt{ }$ & $\sqrt{ }$ & $\sqrt{ }$ & $\sqrt{ }$ & $\begin{array}{l}\text { (Sabol, 2008; Omar, } \\
\text { 2015) }\end{array}$ \\
\hline 32 & $\begin{array}{l}\text { Facility maintenance (easy access to } \\
\text { data for efficient } O \& M \text { ) }\end{array}$ & $\sqrt{ }$ & $\sqrt{ }$ & $\sqrt{ }$ & $\sqrt{ }$ & $\sqrt{ }$ & $\sqrt{ }$ & $\begin{array}{l}\text { (Elhendawi, et al., } \\
\text { 2019) }\end{array}$ \\
\hline 33 & $\begin{array}{l}\text { Reduced claims and legal cases (reduced } \\
\text { litigation and dispute claims) }\end{array}$ & $\sqrt{ }$ & $\sqrt{ }$ & $\sqrt{ }$ & $\sqrt{ }$ & $\sqrt{ }$ & $\sqrt{ }$ & $\begin{array}{l}\text { (Liu, et al., 2010; } \\
\text { Construction, M.H, } \\
\text { 2012) }\end{array}$ \\
\hline 34 & Improved accuracy & $\sqrt{ }$ & $\sqrt{ }$ & $\sqrt{ }$ & $\sqrt{ }$ & $\sqrt{ }$ & $\sqrt{ }$ & (Liu, et al., 2010) \\
\hline 35 & Promote profits & $\sqrt{ }$ & $\sqrt{ }$ & $\sqrt{ }$ & $\sqrt{ }$ & $\sqrt{ }$ & $\sqrt{ }$ & $\begin{array}{l}\text { (Construction, M.H, } \\
\text { 2012) }\end{array}$ \\
\hline 36 & $\begin{array}{l}\text { Punctual procurement (reduce the } \\
\text { inventory duration and order materials } \\
\text { Just In Time) }\end{array}$ & $\sqrt{ }$ & $\sqrt{ }$ & $\sqrt{ }$ & $\sqrt{ }$ & $\sqrt{ }$ & $\sqrt{ }$ & $\begin{array}{l}\text { (Chan, 2014; Gerges, } \\
\text { et al., 2016) }\end{array}$ \\
\hline 37 & Promote prefabrication for better quality & $\sqrt{ }$ & $\mathrm{x}$ & $\sqrt{ }$ & $\sqrt{ }$ & $\sqrt{ }$ & $\sqrt{ }$ & $\begin{array}{l}\text { (Elbeltagi \& Dawood, } \\
\text { 2011; Bryde, et al., } \\
\text { 2013) }\end{array}$ \\
\hline 38 & $\begin{array}{l}\text { Designers becoming more } \\
\text { knowledgeable in the construction } \\
\text { processes }\end{array}$ & $\sqrt{ }$ & $\sqrt{ }$ & $\sqrt{ }$ & $\sqrt{ }$ & $\sqrt{ }$ & $\sqrt{ }$ & (McCartney, 2010) \\
\hline 39 & Maintain repeat business & $\sqrt{ }$ & $\sqrt{ }$ & $\sqrt{ }$ & $\sqrt{ }$ & $\sqrt{ }$ & $\sqrt{ }$ & $\begin{array}{l}\text { (Construction, M.H, } \\
\text { 2012) }\end{array}$ \\
\hline 40 & $\begin{array}{l}\text { Market new business (offers new } \\
\text { services such as reality capture) }\end{array}$ & $\sqrt{ }$ & $\sqrt{ }$ & $\sqrt{ }$ & $\sqrt{ }$ & $\sqrt{ }$ & $\sqrt{ }$ & $\begin{array}{l}\text { (Construction, M.H, } \\
\text { 2012) }\end{array}$ \\
\hline 41 & Better distribution for human resources & $\sqrt{ }$ & $\sqrt{ }$ & $\sqrt{ }$ & $\sqrt{ }$ & $\sqrt{ }$ & $\sqrt{ }$ & $\begin{array}{l}\text { (Construction, M.H, } \\
\text { 2012; Chan, 2014) }\end{array}$ \\
\hline 42 & $\begin{array}{l}\text { Quick and easy integration of new team } \\
\text { members }\end{array}$ & $\sqrt{ }$ & $\sqrt{ }$ & $\sqrt{ }$ & $\sqrt{ }$ & $\sqrt{ }$ & $\sqrt{ }$ & (Jernigan, 2014) \\
\hline 43 & Overcoming distance barriers & $\sqrt{ }$ & $\sqrt{ }$ & $\sqrt{ }$ & $\sqrt{ }$ & $\sqrt{ }$ & $\sqrt{ }$ & (Eastman, et al., 2011) \\
\hline
\end{tabular}


Dec - 2019; Volume: 2 Issue: 2 page: 01-22

ISSN 2571-1075

\begin{tabular}{|c|c|c|c|c|c|c|c|c|}
\hline 44 & $\begin{array}{l}\text { Promote the designers' capacity and } \\
\text { increase the competition }\end{array}$ & $\sqrt{ }$ & $\sqrt{ }$ & $\sqrt{ }$ & $\sqrt{ }$ & $\sqrt{ }$ & $\sqrt{ }$ & $\begin{array}{l}\text { (Eastman, et al., 2011; } \\
\text { Samuelson \& Björk, } \\
\text { 2013) }\end{array}$ \\
\hline 45 & $\begin{array}{l}\text { Bridge the capacity gaps with the } \\
\text { international AEC professionals }\end{array}$ & $\sqrt{ }$ & $\sqrt{ }$ & $\sqrt{ }$ & $\sqrt{ }$ & $\sqrt{ }$ & $\sqrt{ }$ & (Eastman, et al., 2011) \\
\hline 46 & $\begin{array}{l}\text { As-built drawings (laser scanning for } \\
\text { existing properties) }\end{array}$ & $\sqrt{ }$ & $\sqrt{ }$ & $\sqrt{ }$ & $\mathrm{x}$ & $\sqrt{ }$ & $\sqrt{ }$ & $\begin{array}{l}\text { (Love, et al., 2014; } \\
\text { Volk, et al., 2014) }\end{array}$ \\
\hline 47 & $\begin{array}{l}\text { Computer-aided facility management } \\
(\mathrm{CAFM}) \text { information requirement }\end{array}$ & $\sqrt{ }$ & $\sqrt{ }$ & $\sqrt{ }$ & $\sqrt{ }$ & $\sqrt{ }$ & $\sqrt{ }$ & $\begin{array}{l}\text { (Elhendawi, et al., } \\
\text { 2019) }\end{array}$ \\
\hline 48 & $\begin{array}{l}\text { Offsite accessibility, access the model } \\
\text { and project details from anywhere }\end{array}$ & $\sqrt{ }$ & $\sqrt{ }$ & $\sqrt{ }$ & $\sqrt{ }$ & $\sqrt{ }$ & $\sqrt{ }$ & (Autodesk, 2015) \\
\hline 49 & $\begin{array}{l}\text { Augmented reality for interactive } \\
\text { architectural visualisation }\end{array}$ & $\sqrt{ }$ & $\sqrt{ }$ & $\sqrt{ }$ & $\sqrt{ }$ & $\sqrt{ }$ & $\sqrt{ }$ & $\begin{array}{l}\text { (Wang, et al., 2014; } \\
\text { Omar, 2015) }\end{array}$ \\
\hline 50 & GIS integrated with BIM & $\sqrt{ }$ & $\sqrt{ }$ & $\sqrt{ }$ & $x$ & $\sqrt{ }$ & $x$ & (Baik, et al., 2015) \\
\hline 51 & $\begin{array}{l}\text { Conformity with specifications, } \\
\text { standards, and codes }\end{array}$ & $\sqrt{ }$ & $\sqrt{ }$ & $\sqrt{ }$ & $\sqrt{ }$ & $\sqrt{ }$ & $\sqrt{ }$ & $\begin{array}{l}\text { (Eastman, et al., 2011; } \\
\text { Sebastian, 2011) }\end{array}$ \\
\hline
\end{tabular}

*C (Client), A/E (Architect/Engineer), C/SC (Contractor/Subcontractor), S (Supplier), OS (Other Stakeholders), FM (Facility Management)

Eastman et al. (2008) claimed that the client is the only party reaping the full benefits of BIM. This claim aligns with the findings in Table (1), which explicitly demonstrated that the client is the party benefitting most from the implementation of BIM with the highest score of benefits i.e. 51 out of 51 . However, each party acquires the benefits of BIM based on their business function.

Salla (2014) summarised the top fifteen benefits gained from using BIM in the following order; (1) Reduce errors and omissions in the design phase, (2) Improve collaboration with owner/design firms during the construction phase, (3) Enhance organisational image, (4) Reduce rework, (5) Lower construction cost, (6) Improve cost control and predictability, (7) Reduce the overall project duration, (8) Market new business, (9) Offer new services, (10) Increase profits, (11) Maintain business sustainability, (12) Reduce cycle time of workflows, (13) Faster client approval cycles, (14) Improve safety, (15) Faster regulatory approval cycles.

\subsection{BIM Barriers}

Azhar et al., (2015) reported that, despite the advantages of implementing BIM in construction projects and the rapid growth of BIM adoption, several organisations in developing countries are facing various challenges and obstacles hindering the implementation of BIM, which has made it a laborious task. Barriers of BIM are perceived differently from two points of view, those of BIM users and those of non-users (Eadie, et al., 2014).

Panuwatwanich, et al., (2013) and Omar (2015) highlighted the top barriers for implementing BIM, are "lack of management commitment to implement BIM" and "the remarkable lack of know-how to switch to BIM and to manage the challenges and obstacles". Above all, "the resistance to change, and clinging to the old ways of working" was reported as the major reason for the cumbersome adoption of BIM in the AEC industry, specifically in the Middle East and North Africa (MENA).

According to McGraw-Hill (2012) the top seven barriers that hindered BIM implementation are interoperability, functionality misperception, unidentified BIM deliverables among parties, clients refraining to ask for BIM, shortage of BIM competencies and the need for a 3D building product manufacturer. 
Dec - 2019; Volume: 2 Issue: 2 page: 01-22

Banawi (2017) asserted that, BIM non-users summarised the salient issues precluded implementation of BIM as there is insufficient demand from clients, there has not been sufficient time to evaluate BIM. Moreover, software and hardware upgrades are too expensive. BIM non-users claimed that BIM functionality does not apply very well to what they do and there is insufficient BIM-compatible content available for industry needs. Table (2) portrays the classifications of the barriers and classifies them into: Personal Barriers, Process Barriers, Business Barriers, Technical Barriers, Organization Barriers and Market Barriers.

Table 2: BIM Recognized Barriers for the AEC industry

\begin{tabular}{|c|c|c|}
\hline No. & The barriers & Authors \\
\hline \multicolumn{3}{|c|}{ Personal Barriers } \\
\hline 1 & Insufficient education and training & (Banawi, 2017; Matarneh \& Hamed, 2017) \\
\hline 2 & Lack of true understanding of what BIM is & $\begin{array}{l}\text { (Bryde, et al., 2013; Alhumayn, et al., } \\
\text { 2017) }\end{array}$ \\
\hline 3 & Cultural issues resulting in resistance to change & (Almutiri, 2016; Gerges, M, et al., 2017) \\
\hline 4 & $\begin{array}{l}\text { Lack of BIM knowledge pertaining to current and emerging } \\
\text { technologies }\end{array}$ & (Saleh, 2015) \\
\hline \multicolumn{3}{|c|}{ BIM Process Barriers } \\
\hline 1 & The required collaboration, integration, and interoperability & (Banawi, 2017) \\
\hline 2 & Not all stakeholders are using BIM & $\begin{array}{l}\text { (Linderoth, 2010; Elmualim \& Gilder, } \\
\text { 2014) }\end{array}$ \\
\hline 3 & $\begin{array}{l}\text { Legal and contractual challenges } \\
\text { (ownership of data, traditional procurement methodology) }\end{array}$ & $\begin{array}{l}\text { (Chien, et al., 2014; Eadie, et al., 2014; } \\
\text { Azhar, et al., 2015). }\end{array}$ \\
\hline 4 & Risks and challenges with the use of a single model (BIM) & (Saleh, 2015; Banawi, 2017) \\
\hline 5 & $\begin{array}{l}\text { Changing work processes (Lack of effective collaboration among } \\
\text { project participants) }\end{array}$ & (Saleh, 2015) \\
\hline \multicolumn{3}{|c|}{ Business Barriers } \\
\hline 1 & Time and cost required to train new users & (Gerges, et al., 2016) \\
\hline 2 & $\begin{array}{l}\text { Cost implications at the outset of BIM implementation pertaining to } \\
\text { purchasing software licenses, hardware upgrade, training cost and time }\end{array}$ & $\begin{array}{l}\text { (Gerges, et al., 2016; Gerges, M, et al., } \\
\text { 2017; Matarneh \& Hamed, 2017) }\end{array}$ \\
\hline 3 & Unclear benefits & (Construction, M.H, 2012; Saleh, 2015) \\
\hline 4 & The complicated and time-consuming modeling process & $\begin{array}{l}\text { (Alhumayn, et al., 2017; Gerges, M, et al., } \\
\text { 2017) }\end{array}$ \\
\hline 5 & $\begin{array}{l}\text { Have not had sufficient time to Evaluate, most construction players } \\
\text { adopt "watch and see" strategy }\end{array}$ & (Construction, M.H, 2012; Omar, 2015) \\
\hline 6 & Uncertainty for Return on Investment (ROI) & (Azhar, 2011; Saleh, 2015) \\
\hline 7 & Lack of contractual arrangements & $\begin{array}{l}\text { (Harrison \& Thurnell, 2014; Banawi, } \\
\text { 2017) }\end{array}$ \\
\hline 8 & Absence of imperative policy from the government to mandate BIM & (Elhendawi, et al., 2019) \\
\hline \multicolumn{3}{|c|}{ Technical barriers } \\
\hline 1 & Lack of BIM specialists & (Bui, et al., 2016; Gerges, M, et al., 2017) \\
\hline 2 & Absence of customised standards and clear guidelines & $\begin{array}{l}\text { (Volk, et al., 2014; Matarneh \& Hamed, } \\
\text { 2017) }\end{array}$ \\
\hline 3 & Difficulty of updating the information in BIM (time-consuming) & (Chan, 2014; Volk, et al., 2014) \\
\hline 4 & $\begin{array}{l}\text { BIM still utilized as a tool i.e. "object-based modeling" or "model- } \\
\text { based collaboration", whereas BIM users should seek to reach to } \\
\text { "network-based integration" }\end{array}$ & (Succar, et al., 2013) \\
\hline 5 & Insufficient infrastructure-based technology & (Chan, 2014; Bui, et al., 2016) \\
\hline
\end{tabular}


Dec - 2019; Volume: 2 Issue: 2 page: 01-22

ISSN 2571-1075

\begin{tabular}{|c|c|c|}
\hline 6 & Inefficient Interoperability & (Chan, 2014) \\
\hline 7 & $\begin{array}{l}\text { BIM file sizes are too large. Transporting, manipulating, storing or } \\
\text { sharing these large files is difficult }\end{array}$ & (Liu, et al., 2010) \\
\hline 8 & Updating of information & (Chan, 2014; Volk, et al., 2014) \\
\hline 9 & Current technology is enough & (Saleh, 2015; Gerges, M, et al., 2017) \\
\hline \multicolumn{3}{|c|}{ Organisation Barriers } \\
\hline 1 & Lack of government support & $\begin{array}{l}\text { (Bui, et al., 2016; Matarneh \& Hamed, } \\
\text { 2017) }\end{array}$ \\
\hline 2 & Difficulties in managing the change to BIM & (Chien, et al., 2014; Azhar, et al., 2015) \\
\hline 3 & Absence of other competing initiatives & (Saleh, 2015; Omar, 2015) \\
\hline 4 & Resistance to change/unwillingness to change & (Jernigan, 2014; Omar, 2015) \\
\hline 5 & $\begin{array}{l}\text { BIM compels drastic changes in the organizational chart and the } \\
\text { workflow }\end{array}$ & $\begin{array}{l}\text { (Memon, et al., 2014; Volk, et al., 2014; } \\
\text { Gerges, M, et al., 2017) }\end{array}$ \\
\hline 6 & $\begin{array}{l}\text { Lack of BIM experience (know-how) to switch from non-BIM to BIM } \\
\text { users }\end{array}$ & (Elhendawi, et al., 2019) \\
\hline 7 & Cost correlated to hardware upgrades and software purchase & $\begin{array}{l}\text { (Arayici, et al., 2009; Construction, M.H, } \\
\text { 2012) }\end{array}$ \\
\hline 8 & Organisational financial stand & (Chien, et al., 2014; Azhar, et al., 2015) \\
\hline \multicolumn{3}{|c|}{ Market Barriers } \\
\hline 1 & Low level of adoption due to poor awareness about BIM & $\begin{array}{l}\text { (Gerges, et al., 2016; Matarneh \& Hamed, } \\
\text { 2017) }\end{array}$ \\
\hline 2 & $\begin{array}{l}\text { The wrong grasp of BIM, as it tends to be introduced by software } \\
\text { developers, accordingly the market is overdue at the embarking stage } \\
\text { for switching to BIM }\end{array}$ & (Porwal \& Hewage, 2013; Banawi, 2017) \\
\hline 3 & Lack of client/government demand & $\begin{array}{l}\text { (Gerges, et al., 2016; Gerges, M, et al., } \\
\text { 2017) }\end{array}$ \\
\hline 4 & Clients not lending appropriate support to the benefits of BIM & (Banawi, 2017) \\
\hline
\end{tabular}

Based on the extensive literature survey, there is a duet of BIM benefits and there is a lack of consensus on the barriers. In order to bridge this gap in knowledge, this research investigated these benefits and barriers and paves the way for swift and smooth implementation of BIM.

\section{Research Methodology and Data Collection:}

The literature review developed a profound understanding of the perceived benefits and barriers that hindered the implementation of BIM. The research adopted the overarching method, which involved a quantitative approach via a structured questionnaire, followed by a qualitative approach via face-to-face interviews with carefully selected veterans from the KSA construction industry.

The Kingdom of Saudi Arabia (KSA) provides a good example to represent the developing countries in the Middle East that suffer from the barriers and obstacles overburdening the implementation of BIM. Moreover, KSA embraces several international organizations originating in developed countries, which bring good experience in the BIM realm.

The literature study assisted the development of a structured questionnaire survey. This survey was distributed via email to randomly selected professionals who work in the KSA, especially, those who are registered in Saudi Commerce Chambers which includes the entire KSA AEC industry players. In addition to organisations that are registered in the Ministry of Municipal and Rural Affairs, additionally, Saudi Council of Engineers published the questionnaire in its monthly magazine. 
Pilot sample: Prior to finalising the questionnaire, the survey was distributed to a pilot sample of a randomly selected 12 professionals with average experience of 8 years in the KSA AEC industry. Half of them represented BIM users and the other half represented non-users. These veteran professionals were selected from local and multinational AEC organisations in the KSA market. The initial questionnaire was refined based on the feedback received from the pilot sample.

Afterwards, the final questionnaire was accessible via the online survey platform "Google forms". This platform enabled easy and swift completion of the survey via the internet and then the responses were gathered automatically to save and store them via an online database.

Traditionally, the response rate for online surveys is suboptimal by $11 \%$ compared with other techniques (Saunders, et al., 2012). The link to an online questionnaire was sent by email to increase confidentiality and anonymity. The questionnaire was available from $20^{\text {th }}$ September 2019 to $20^{\text {th }}$ December 2019.

The questionnaire survey consisted of ten sections. Section one consisted of general information, respondents' personal information and demographics such as profession, years of experience in KSA, academic qualifications. Section two consisted of respondents' awareness of BIM, BIM user or nonuser, BIM Software that their company use, BIM applications, beneficial integrating with BIM, BIM maturity levels, the future of BIM .... etc. In section 5, 6, 7, 8, 9 and 10 each respondent was asked to rate to what extent he/she agrees/disagrees with each of the perceived benefits of BIM, and barriers for BIM implementation on a five-point Likert scale ranging from 1 to 5, where 5 represents 'Strongly agree', and 1 represents "Strongly disagree".

The questionnaire was developed to collect the data from BIM users and BIM non-users who worked in the KSA AEC industry. The questionnaire survey was sent to 689 AEC medium to large organisations in the KSA. There were 275 responses (40\%), but of those, incomplete responses were $27(9.7 \%)$ of the returned responses. Therefore, the number of true responses was $248(90 \%)$ of the returned responses.

\section{Results analysis:}

\subsection{Respondents' general information}

The received responses are 248 while $63 \%$ of the respondents do not have enough knowledge about BIM. However, 37\% have good BIM knowledge. This percentage unveiled that there is a lack of awareness about BIM in the KSA. In fact, this recent survey opposes the conclusion made by Farah (2014) who reported that there is a high level of awareness of BIM in the KSA AEC industry. Figure (1) demonstrates the reasons for which some respondents are reluctant to adopt BIM. 


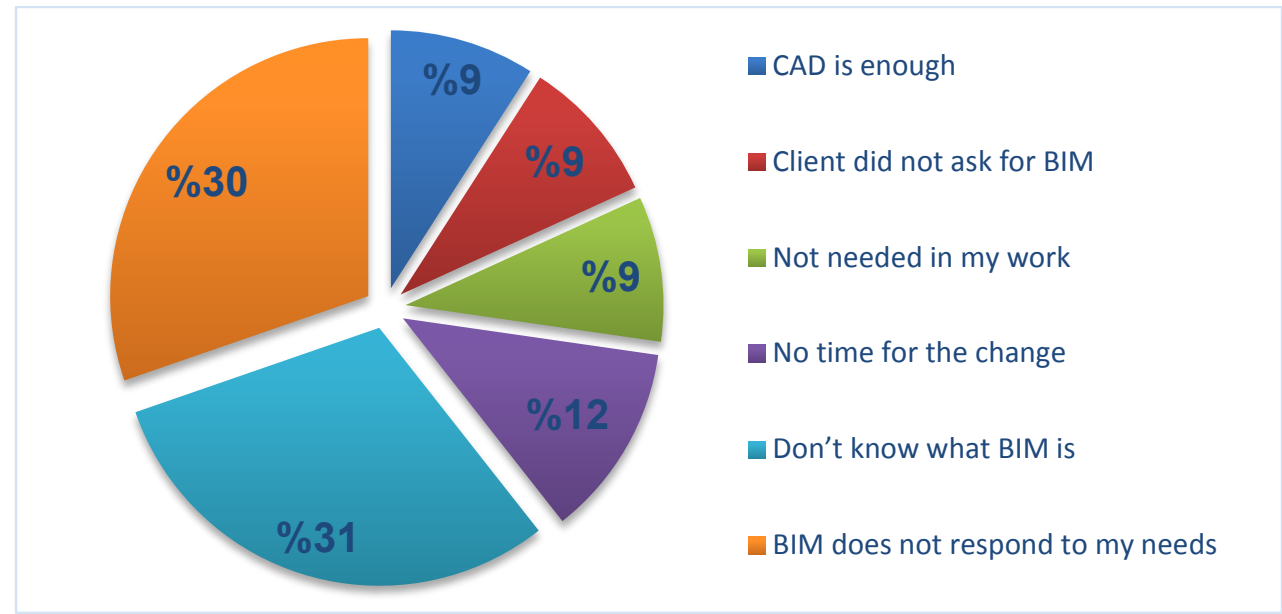

Figure 1: Reasons for which BIM non-users are not interested in BIM adoption

It is obvious, "the lack of awareness of what BIM is" is the main hindrance precluding the adoption of BIM in the KSA. Consequently, BIM non-users do not know how to leverage the benefits from BIM. This warrants crucial action from the government and its subsidiaries to raise the awareness for BIM non-users, and to recognise the utilities of BIM. It is worthy to mention that, the true completed responses represented $25.5 \%$ public organisations and $74.5 \%$ private organisations. This portrays that the public sector is less interested in BIM compared with the private sector who embraces various international organisations.

Figure 2 illustrates that, about $50 \%$ of respondents have less than 10 years of BIM experience, which reflects the low level of BIM awareness. Raising the awareness among the AEC industry plays pivotal role for overcoming the barriers and obstacles that hinder BIM implementation. Furthermore, raising awareness of BIM for undergraduate and post graduate students is seen as the cornerstone to develop a new generation with BIM knowledge.

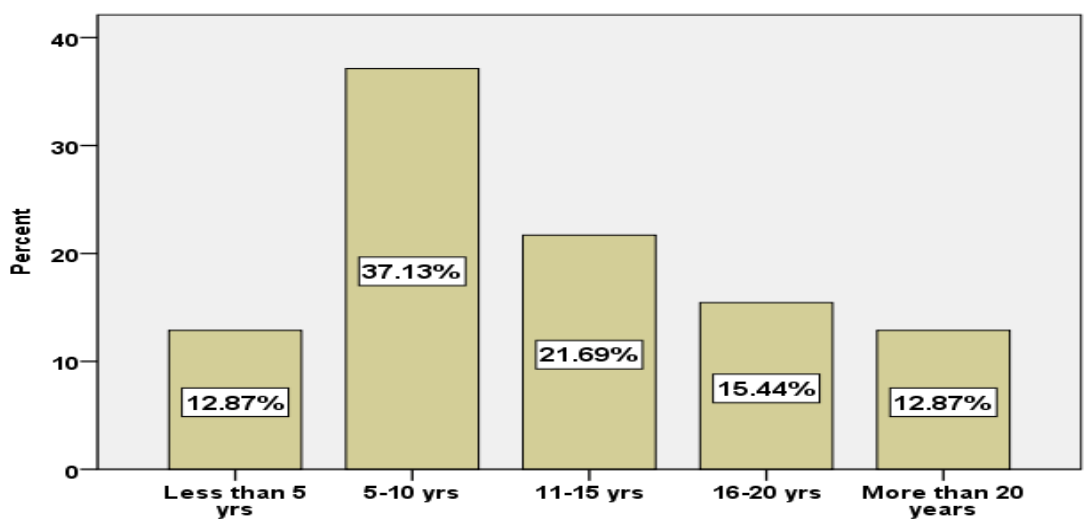

Figure 2: Respondents years of experience

\subsection{Respondents perceptions about BIM}

The respondents' answers for different areas of BIM application are reported in Table (3). This result conforms with several claims in the literature studies. 
Table 3: BIM Applications

\begin{tabular}{|l|c|c|}
\hline \multicolumn{1}{|c|}{ BIM Applications } & \multicolumn{2}{c|}{ Responses } \\
\cline { 2 - 3 } & $\mathrm{N}$ & Percent \\
\hline Safety & 23 & $4.1 \%$ \\
Interaction with non-professionals & 38 & $6.8 \%$ \\
Site layout planning & 42 & $7.6 \%$ \\
Support constructability and analysis & 42 & $7.6 \%$ \\
Collaboration & 47 & $8.5 \%$ \\
Project scheduling and programming & 52 & $9.4 \%$ \\
Material take-off for tendering & 53 & $9.5 \%$ \\
Cost Estimating & 60 & $10.8 \%$ \\
Design analysis & 62 & $11.2 \%$ \\
Quantity Surveying & 66 & $11.9 \%$ \\
Production of shop-drawings/as-built drawings & 71 & $12.8 \%$ \\
\hline
\end{tabular}

Table (4), presents the various areas that can be integrated with BIM as per the respondents' answers. Project management came as the first area that is usually integrated with BIM. These results coincide with the literature studies.

\section{Table 4: Integration with BIM}

\begin{tabular}{|l|c|c|}
\hline \multicolumn{1}{|c|}{ Integration with BIM } & \multicolumn{2}{|c|}{ Responses } \\
\cline { 2 - 3 } & $\mathrm{N}$ & Percent \\
\hline Health and Safety & 37 & $6.4 \%$ \\
Augmented reality & 38 & $6.6 \%$ \\
Enterprise Resource Planning (ERP) & 39 & $6.8 \%$ \\
Computer-aided facility management (CAFM) & 39 & $6.8 \%$ \\
Geography information system (GIS) & 41 & $7.1 \%$ \\
Facility Maintenance & 45 & $7.8 \%$ \\
Integrated Project Delivery (IPD) & 48 & $8.4 \%$ \\
Construction Management Education & 49 & $8.5 \%$ \\
Lean Construction & 50 & $8.7 \%$ \\
Green Building & 54 & $9.4 \%$ \\
Virtual Reality & 57 & $9.9 \%$ \\
Project Management & 77 & $13.4 \%$ \\
\hline
\end{tabular}

Figure 3 measured the maturity levels of BIM amongst the BIM user participants, showing that BIM adoption is still within level 1, with a percentage of $35.51 \%$. These results support the authors' claim that "the developing countries are still struggling in the embarkation stage of BIM implementation".

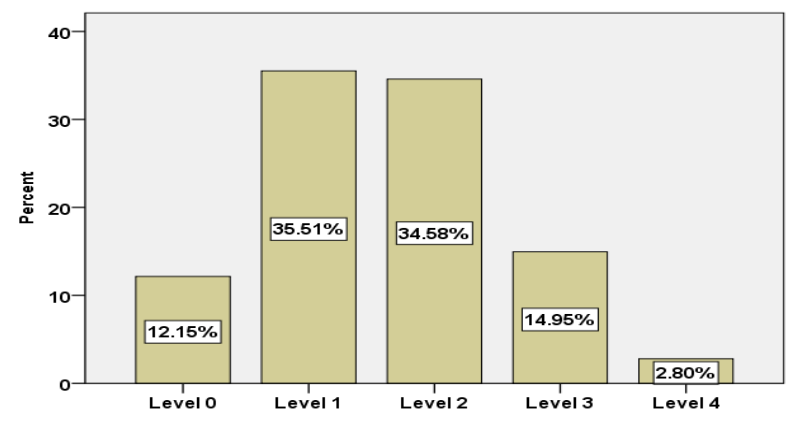

Figure 3: BIM maturity levels

As BIM is still in its embarking stage it is realistic to find that most BIM users are utilizing BIM as a 3D model. Figure (4) shows that more than 67\% of BIM users utilize BIM only for 3D modelling. 


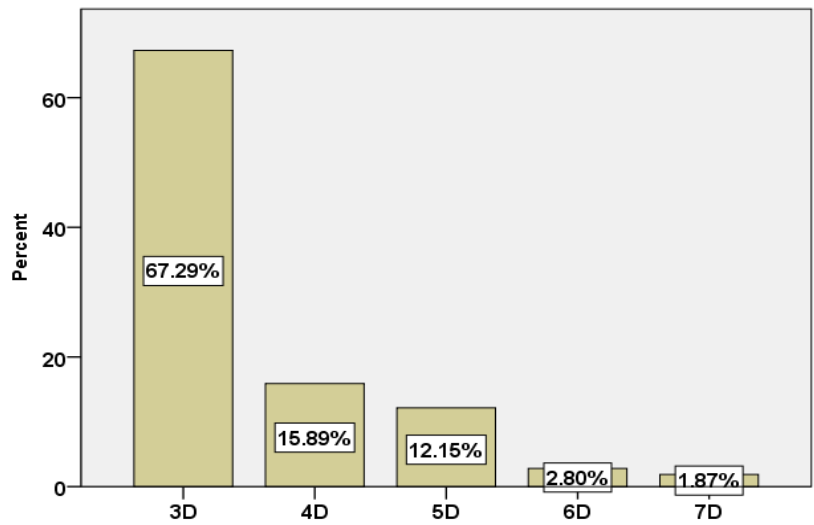

Figure 4: The current implementing Dimension of BIM in respondents' projects

As BIM is rapidly growing worldwide, Figure 5 shows that more than $70 \%$ of respondents expect that BIM will sooner or later be mandated in the AEC industry worldwide.

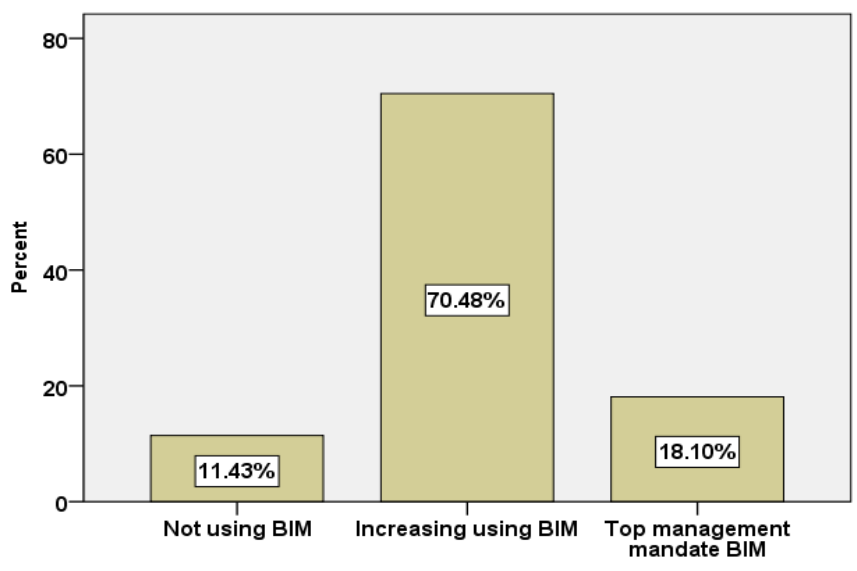

Figure 5: The future of BIM

\subsection{Perceived benefits of BIM}

There is a close understanding of the perceived benefits of BIM between the BIM users and non-users, chiefly the advantage of meeting client satisfaction. BIM users believe in the capability of BIM to consolidate the team works and provide a competitive advantage to the firm much higher than BIM non-users, it is realistic, because only BIM users can acquire these advantages.

Generally, the expectations of BIM non-users are much more than BIM users pursuant to the advantages of BIM. The biggest difference for the perceptions of the two groups is found in the ability of BIM to "save the time" which was considered the first by BIM non-users and at the end by BIM users. Similarly, for the benefit "BIM offers improved productivity". These big discrepancies can be understood from the ideal state that BIM non-users are considering, which can be achieved only after the AEC market reaches the full maturity level of BIM. 


\subsubsection{Client perspective}

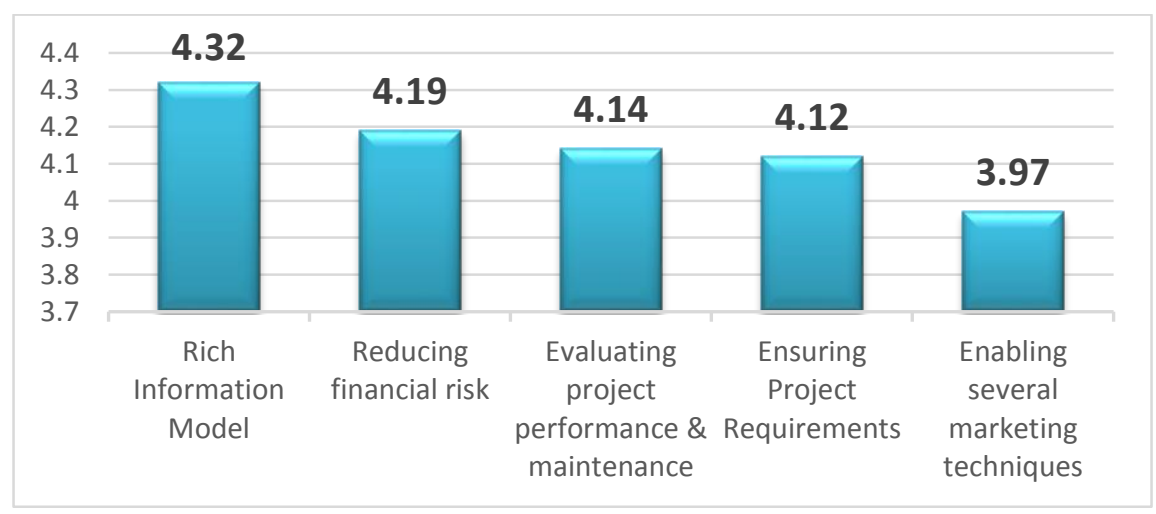

Figure 6: Benefits of BIM from the Client's perspective

Figure 6 portrays the client responses. Respondents claim that benefits of BIM from clients' perspectives are as follows: BIM is distinctive to clients for time-saving, completing projects on time, minimising coordination problems, improving quality, assuring like for like comparison during the tender stage, earlier involvement of client in the design stage and reducing cost. Furthermore, some respondents emphasised the crucial need to start BIM at the outset of the project, not at a later stage as it disturbs the processes which may cause delays instead of progress.

\subsubsection{Designer perspective}

Table 5 shows the designers' responses for their perceived benefits of BIM. They have considered BIM is distinctive for enhancing their experience through allowing various options in a short duration, quick review, and the time required to make changes on the model is very short compared with CAD conventional approaches. Moreover, BIM improves coordination, avoids clashes and tremendously reduces design errors. It also boosts information sharing and enables quick quantity take-off. Ahmed, et al. (2018) mentioned, the aforementioned benefits of BIM as generic benefits for all project parties.

Table 5: Benefits of BIM from the Designers' perspective

\begin{tabular}{|l|c|c|c|c|}
\hline \multicolumn{1}{|c|}{ Benefits } & $\begin{array}{c}\text { Weighted } \\
\text { mean }\end{array}$ & $\begin{array}{c}\text { Std. } \\
\text { Deviation }\end{array}$ & Ranking & $\begin{array}{c}\text { The general } \\
\text { trend }\end{array}$ \\
\hline Producing Various design options & 3.97 & 1.045 & 3 & Agree \\
\hline Facilitating visual evacuation plans & 4.06 & .864 & 1 & Agree \\
\hline Enabling Sustainable analysis & 3.98 & .980 & 2 & Agree \\
\hline Extracting fast IFC drawings & 3.97 & 1.045 & 3 & Agree \\
\hline Weighted mean & $\mathbf{3 . 9 9 5}$ & & & Agree \\
\hline
\end{tabular}

\subsubsection{Contractor perspective}

Figure 7 illustrates the contractors' responses for their perceived benefits of BIM. They have considered BIM is distinctive for improving coordination and collaboration among different project stakeholders, it enables cost savings, allows visualisations that give a clear and full picture for effective planning, BIM tools assist the project team to reduce the cost and control the budget. Clash detection tool enables detection of clashes in the design prior to starting construction, which reduces conflicts and disputes. 4D BIM tool enables accurate inventory, improves facility management and increases productivity. 


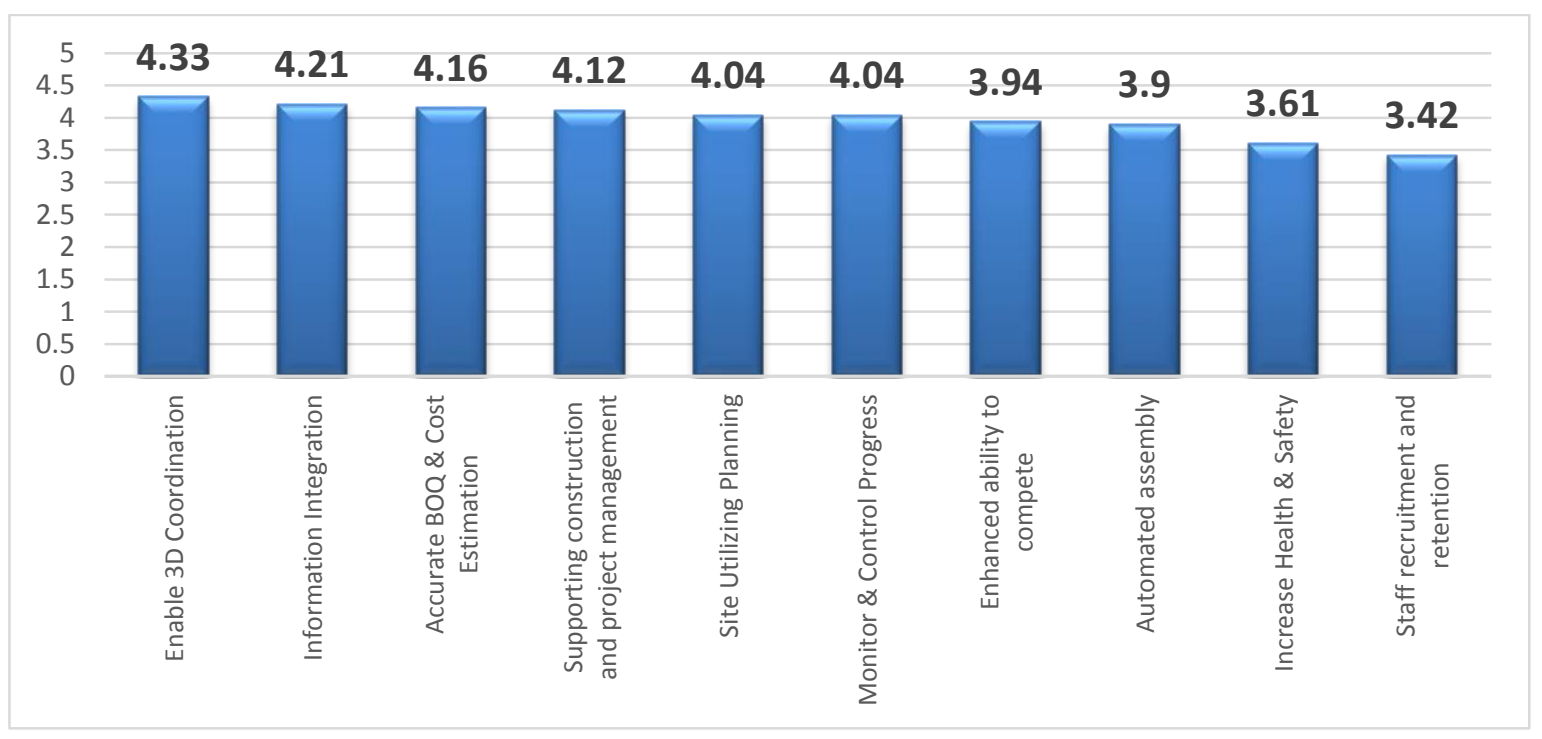

Figure 7: Benefits of BIM from the contractors' perspective

One respondent concluded that BIM provides excellent coordination, good presentation and predicts issues before their occurrence. Furthermore, another respondent pointed out that BIM enhances bid accuracy with model-based estimation and improved coordination with schedule visualisation. These results align with the conclusions of (Bui, et al., 2016).

\subsubsection{Common benefits (to all participants)}

According to the data analysis, the common benefits of BIM that all disciplines have experienced are ranked hereinafter in Table 6.

Table 6: Benefits of BIM to all participants (i.e. client, designer, and contractor)

\begin{tabular}{|l|c|c|c|c|}
\hline \multicolumn{1}{|c|}{ Benefits } & $\begin{array}{c}\text { Weighted } \\
\text { mean }\end{array}$ & $\begin{array}{c}\text { Std. } \\
\text { Deviation }\end{array}$ & order & $\begin{array}{c}\text { The general } \\
\text { trend }\end{array}$ \\
\hline Time savings & 4.20 & 1.035 & 2 & Agree \\
\hline Cost saving & 4.12 & 1.082 & 5 & Agree \\
\hline Quality improvement and Reduced Rework & 4.19 & 1.062 & 3 & Agree \\
\hline Clash detection & 4.29 & 1.094 & 1 & Strongly agree \\
\hline Improves visualisation & 4.06 & 1.096 & 7 & Agree \\
\hline Reduced number of requests for information & 4.06 & 1.096 & 7 & Agree \\
\hline Reduced change orders & 4.06 & 1.096 & 7 & Agree \\
\hline Enhanced collaboration and communication & 4.16 & 1.035 & 4 & Agree \\
\hline Reduced document errors & 4.10 & 1.052 & 6 & Agree \\
\hline Reduced disputes, claims and lawful issues & 3.90 & 1.052 & 9 & Agree \\
\hline Reduced waste and promotes value engineering & 3.98 & 1.097 & 8 & Agree \\
\hline Increasing efficiency & 4.19 & 1.050 & 3 & Agree \\
\hline Creation and sharing of information ability: Life cycle data & 4.12 & 1.100 & 5 & Agree \\
\hline Weighted mean & 4.11 & & & Agree \\
\hline
\end{tabular}


Figure (8) shows the benefits to all project parties. Clearly the client is the most benefited party from BIM followed by designers and contractors. This result is close to Eastman, et al., (2008) conclusions, wherein, they ordered the BIM beneficiaries as the client, then design bodies and the contractor.

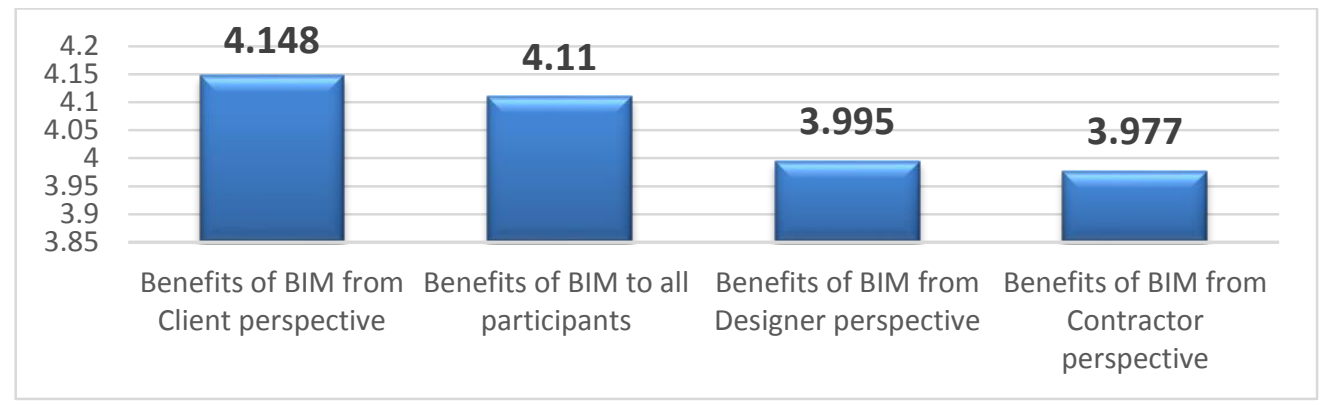

Figure 8: Perceived benefits of BIM

\subsection{Salient Barriers Detering BIM Implementation}

Data analysis explicitly manifesting that, challenges are keyed to change management alongside lack of competencies are the main barriers hindering the wide adoption of BIM. Additionally, the absence of government imperative policy for mandating BIM resulted in poor adoption of BIM as it became an optional choice, for which most of SMEs averted utilisingutilizing BIM.

\subsubsection{Personal Barriers}

\begin{tabular}{|c|c|c|c|c|c|}
\hline \multirow{3}{*}{$\begin{array}{r}4.1 \\
4.05 \\
4 \\
4.95 \\
3.9 \\
3.85\end{array}$} & 4.08 & 4.08 & 4.06 & & \\
\hline & & & & 3.97 & 3.95 \\
\hline & $\begin{array}{c}\text { Lack of } \\
\text { understanding of } \\
\text { BIM and its benefits }\end{array}$ & $\begin{array}{c}\text { Resistance to } \\
\text { change: Lack of } \\
\text { skills development }\end{array}$ & $\begin{array}{l}\text { Lack of BIM } \\
\text { knowledge in } \\
\text { applying current } \\
\text { technologies }\end{array}$ & $\begin{array}{l}\text { Lack of BIM } \\
\text { education }\end{array}$ & $\begin{array}{c}\text { Lack of insufficient } \\
\text { training }\end{array}$ \\
\hline
\end{tabular}

\section{Figure 9: Personal Barriers}

Figure 9 illustrates the personal correlated barriers that diminish implementation of BIM. Respondents reported that the personal barriers could be cultural issues, in that many people involved in a construction area are afraid to share their data for lack of mutual trust and other reasons, lack of advertisement in magazine and news on TV, insufficient fund, shared risk-reward, and lack of conduct long-term relationships.

Pursuant to the data analysis, "resistance to change" and the implicit feeling of being safe in the comfort zone, deters any advocate for change. Moreover, "lack of understanding of the benefits of BIM, and what BIM is" converted several decision makers to be hostile against the change towards BIM. They even considered BIM is useless and has no value to their business. Lack of sufficient BIM knowledge, training and education are of importance to change the current stagnant status.

A quote from one respondent portrayed lack of BIM knowledge, stating that "I am sure BIM designers do not have the enough experience to develop a cost effective and safe design. Furthermore, Not everything on a computer screen can be built in real life." 


\subsubsection{Process Barriers}

Table 7 illustrates the respondents' perception of process barriers. They have considered "changing the work processes" alongside "lack of effective collaboration among project participants" are the most influential attributes that hindered BIM implementation. Moreover, the risks and challenges of using a single model was ranked the second factor that hindered the utiliasation of BIM. However, legal issues pertaining to the model ownership ranked the last as several contract documents still overlook this issue and disputes loom after the project completion between the design bodies and the client.

Table 7: BIM Process Barriers

\begin{tabular}{|l|c|c|c|c|}
\hline \multicolumn{1}{|c|}{ Barriers } & $\begin{array}{c}\text { Weighted } \\
\text { mean }\end{array}$ & $\begin{array}{c}\text { Std. } \\
\text { Deviation }\end{array}$ & Ranking & $\begin{array}{c}\text { The general } \\
\text { trend }\end{array}$ \\
\hline Legal issues (ownership of the model) & 3.51 & 1.033 & 3 & Agree \\
\hline Risks and challenges with the use of a single model (BIM) & 3.57 & 1.031 & 2 & Agree \\
\hline Changing work processes & 3.78 & 1.032 & 1 & Agree \\
\hline Lack of effective collaboration among project participants & 3.78 & 1.032 & 1 & Agree \\
\hline Weighted mean & & $\mathbf{3 . 6 6}$ & & Agree \\
\hline
\end{tabular}

\subsubsection{Business Barriers}

Figure 10 demonstrates the business barriers that impacted BIM implementation. Data analysis revealed that, the time and cost to train the staff ranked as the most significant factor deter the implementation of BIM, followed by, the lack of contractual agreements that clarifies the responsibility of each party. Moreover, the long time required for developing BIM model and uncertainties for return on investment (ROI) due to high costs of implementation are raised as third, fourth and fifth factors respectively. These results are in agreement with Shaban and Elhendawi (2018) findings.

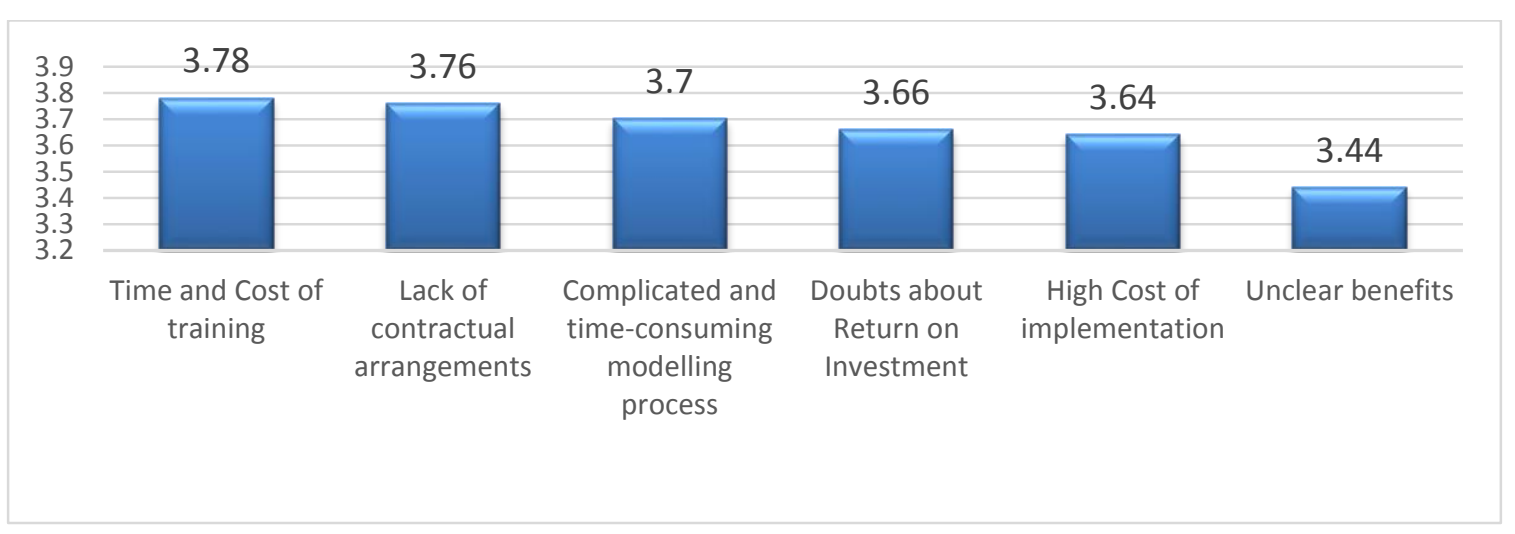

Figure 10: Business Barriers

\subsubsection{Technical Barriers}

Table 8 summarises the respondents' perspectives about technical barriers. Respondents considered "lack of BIM technical experts" has the most devastative impacts on the implementation of BIM. Additionally, "Absence of national BIM standards and clear guidelines" converted the adoption of BIM as a cumbersome task. Changing or upgrading the technology infrastructure such as upgrading the hardware and purchasing software licenses, and the correlated costs and business disturbance, demotivate decision makers to change towards BIM. 
Dec - 2019; Volume: 2 Issue: 2 page: 01-22

Table 8: Technical Barriers

\begin{tabular}{|l|c|c|c|c|}
\hline \multicolumn{1}{|c|}{ barriers } & Weighted mean & $\begin{array}{c}\text { Std. } \\
\text { Deviation }\end{array}$ & Ranking & $\begin{array}{c}\text { The general } \\
\text { trend }\end{array}$ \\
\hline Lack of BIM technical experts & 3.85 & 1.105 & 1 & Agree \\
\hline Interoperability & 3.66 & 1.027 & 4 & Agree \\
\hline Absence of standards and clear guidelines & 3.78 & 1.076 & 2 & Agree \\
\hline Insufficient technology infrastructure & 3.69 & 1.103 & 3 & Agree \\
\hline Current technology is enough & 3.33 & 1.240 & 5 & Neutral \\
\hline Weighted mean & \multicolumn{3}{|c|}{$\mathbf{3 . 6 6 2}$} & Agree \\
\hline
\end{tabular}

\subsubsection{Organization Barriers}

The organisational barriers are as illustrated in Figure 11. Lack of management support and fear of changes are ranked the first and second most influential factors impeding the implementation of BIM in KSA. Noticeably, these findings are similar to the findings concluded by Shaban and Elhendawi (2018) in Syria. Furthermore, respondents detailed that the organisation barriers stemmed from company policy, futile coordination, top management experience, fear of change, unavailability of competencies, and absence of leadership.

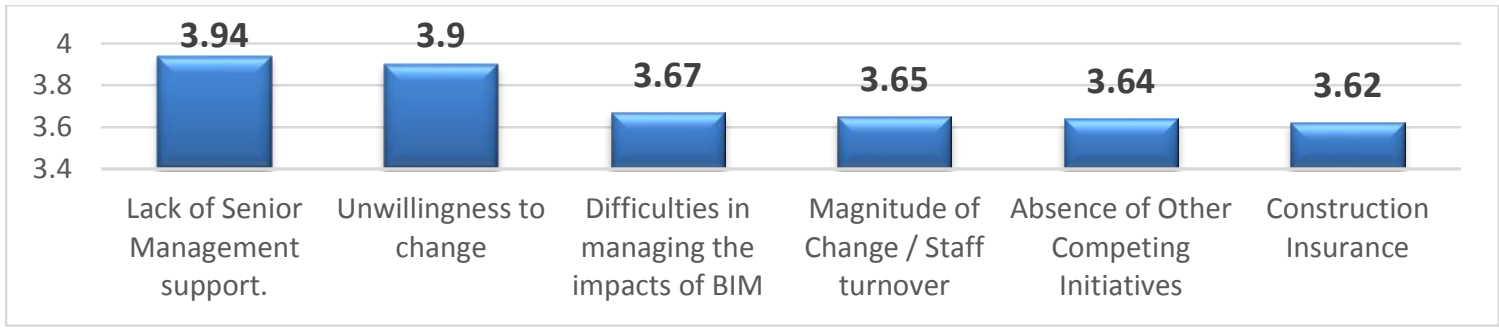

Figure 11: Organisation Barriers

\subsubsection{Market Barriers}

Market barriers are shown in Figure 12. Clearly, the lack of client and/or government demand for BIM was ranked the first as the most important factor that hindered the implementation of BIM. In the same context Omar (2015) claimed that the market is not ready yet. There is a great deal of consensus among the respondents, as there is a significant role incumbent upon the government, to mandate BIM. As such, the market will be ready to adopt BIM.

According to data analysis, the market barriers are seen in the low realization of the benefits of BIM, understanding the importance of BIM, and the lack of competencies as well as stewardship.

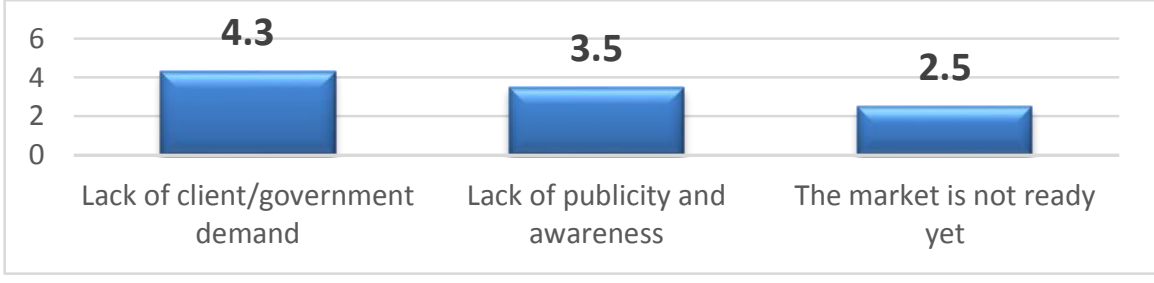

Figure 12: Market Barriers

In order to recognise the hierarchy of the causes that resist the implementation of BIM, Figure (13) illustrates all the six categories under which the challenges were included. It is not a surprise to know that, personal barriers are ranked the first with a significant difference compared to all the other categories. Therefore, plans to propose incentives and catalysts should be put forward to motivate the 
people to adopt BIM. Indeed, BIM has its three pillars which starts with People and then Process and Technology (Eastman et al., 2011).

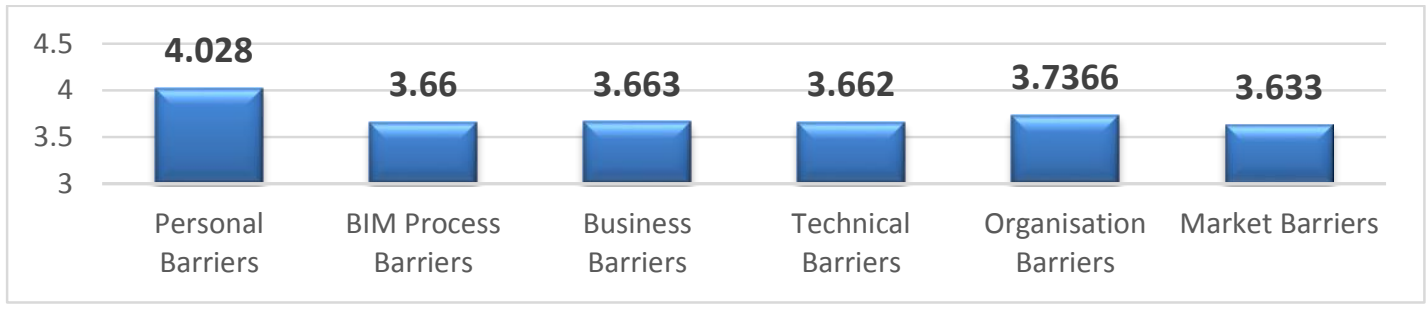

Figure 13: The barriers to implementing BIM

\subsection{Paving the way to facilitate the adoption of BIM}

The respondents recommended several ways to overcome the barriers as follows:

The resistance to change represents the most barriers to hinder BIM implementation and need more effort to remove it. To solve this issue, local companies could seek partnerships with international construction companies that have accomplished projects using BIM-based technologies and processes.

The top management has an indispensable role in leading the organisational change to BIM, so they should be fully aware of the organisational benefits of BIM to improve the performance for adding competitive advantage and increasing the profits. Therefore, top management should be convinced to support this change to take the decision of utilizing BIM.

Furthermore, to expedite BIM implementation the mixed approaches should be adopted concurrently, Bottom-up and top-down. The effective change commences from the employees' which must be supported by top management.

For the sake of providing the market with BIM skilled resources for long term basis, governments should guide and support the universities for the enclosure of BIM within the curriculums for undergraduate and postgraduate students. Moreover, universities together with BIM software vendors should collaborate to raise awareness of BIM throughout series of free training sessions.

Industry Foundation Classes (IFC) enable the opening or importing of BIM files to reuse the created data in other applications using different software; IFC schemes can overcome the conflicts that may appear of using different software of BIM models.

Assigning a model manager or so called BIM manager is essential to manage the BIM model-related issues.

Model correlated issues such as ownership can be easily settled by endorsing a clear clause in the contract documents to clarify this issue. However, New Zealand handbook (2014) have clarified this issue as follows, the designers will acquire a prior consent from the owner to use the model and vice versa, the owner will request the designer's approval to reuse the model.

Integrated project delivery (IPD) was proposed to be the appropriate construction procurement strategy suitable for BIM, where IPD is defined as a "project delivery approach that integrates people, system, business structures, and practices into a process that collaboratively harnesses the talents and insights 
of all participants to optimize project results, increase value of owner, reduce waste, and maximize efficiency through phases of design, fabrication, and construction"

\section{Conclusions:}

The focus of the construction industry now is to eliminate waste and inefficiency to improve quality and profitability. This research extensively investigated the benefits and the barriers that hinder the implementation of BIM within the KSA AEC industry as the cornerstone for proposing solutions to pave the way for KSA construction industry to implement BIM.

The key findings pertaining to the benefits of BIM are: (1) the richness of the information within the BIM Model enhanced the collaboration among stakeholders, (2) Reduced financial risk, (3) Improved project performance, (4) accurate BOQ and cost estimation, (5) promoted the off-site prefabrication, (6) increasing profitability and (7) reduced change orders and disputes.

Moreover, the top barriers deterring BIM implementation are: (1) There is low level of BIM awareness about BIM in the AEC industry, (2) lack of top management support, (3) lack of government demand for BIM, (4) resistance to change, (5) Lack of BIM technical experts and (6) time and cost required for switching to BIM. For appropriate implementation of BIM, lessons learned from earlier BIM users such as UK, USA, Australia, and New Zealand must be taken into consideration to learn from their pitfalls.

This research suggested developing strategic plans relying on collaboration among government, private and public sectors to overcome all barriers. For instance, to overcome insufficient education and training software providers should collaborate with government entities, and universities to educate and train employees and university students (as a long-term solution) to respond to the needs of BIM experts.

\section{References:}

Abbas, A., Din, Z. \& Farooqui, R., 2016. Integration of BIM in construction management education: An overview of Pakistani engineering universities. Procedia Engineering, Volume 145, pp. 151-157.

Abbasnejad, B. \& Moud, H., 2013. BIM and basic challenges associated with its definitions, interpretations and expectations. International Journal of Engineering Research and Applications (IJERA), 3(2), pp. 287-29.

Ahmed, S., Dlask, P., Selim, O. \& Elhendawi, A., 2018. BIM Performance Improvement Framework for Syrian. International Journal of BIM and Engineering Science, 1(1).

Alhumayn, s., Chinyio, E. \& Ndekugri, I., 2017. The Barriers And Strategies Of Implementing Bim In Saudi Arabia. WIT Transactions on The Built Environment, Volume 169, pp. 55-67.

Almutiri, Y., 2016. Empirical investigation into development of a curricular framework to embed building information modelling with undergraduate architectural programmes within Saudi Arabia, Manchester, England,UK: Doctoral dissertation, University of Salford.

Amor, R., Jalaei, F. \& Jrade, A., 214. Integrating Building Information Modeling (BIM) and Energy Analysis Tools with Green Building Certification System to Conceptually Design Sustainable Buildings.. Journal of Information Technology in Construction, Volume 19, pp. 494-519.

Arayici, Y. et al., 2009. BIM implementation for an architectural practice.. Managing It in Construction/Managing Construction for Tomorrow, pp. 689-696. 
Dec - 2019; Volume: 2 Issue: 2 page: 01-22

ISSN 2571-1075

Autodesk Design Academy, 2017. BIM for Construction Management and Planning. [Online] Available at: https://academy.autodesk.com/curriculum/bim-construction-management-and-planning [Accessed 29 October 2017].

Autodesk, 2015. Top 10 Benefits of BIM. [Online] Available at: https://damassets.autodesk.net/content/dam/autodesk/www/campaigns/autocadforconstruction/Autode sk_Top10BenefitsOfBIM.pdf [Accessed 10 September 2017].

Azhar, . S., 2011. Building Information Modeling (BIM): Trends, Benefits, Risks, And Challenges For The AEC Industry. Leadership and management in engineering, 3(11), pp. 241-252.

Azhar, . S., Carlton, W., Olsen, . D. \& Ahmad, . I., 2011. Building information modeling for sustainable design and LEED® rating analysis. Automation in construction, Volume 20(2), pp. 217-224.

Azhar, S., Khalfan, M. \& Maqsood, . T., 2015. Building information modelling (BIM): now and beyond. Construction Economics and Building, 4(12), pp. 15-28.

Baik, A., Yaagoubi, R. \& Boehm, J., 2015. Integration of Jeddah historical BIM and 3D GIS for documentation and restoration of historical monument. International Archives of Photogrammetry, Remote Sensing and Spatial Information Sciences, 40(5), p. 2.

Banawi, A., 2017. Barriers to Implement Building Information Modeling (BIM) in Public Projects in Saudi Arabia. s.l., In International Conference on Applied Human Factors and Ergonomics (pp. 119125). Springer, Cham.

Bryde, D., Broquetas, M. \& Volm, J., 2013. The project benefits of building information modelling (BIM). International journal of project management, 7(31), pp. 971-980.

Bui, N., Merschbrock, C. \& Munkvold, B., 2016. A review of Building Information Modelling for construction in developing countries. Procedia Engineering, Issue 164, pp. 487-494.

Chan, C., 2014. Barriers of implementing BIM in construction industry from the designers' perspective: a Hong Kong experience. Journal of System and Management Sciences, 2(4), pp. 24-40.

Chien, K., Wu, Z. \& Haung, S., 2014. Identifying and assessing critical risk factors for BIM projects: Empirical study. Automation in construction, Volume 45, pp. 1-15.

Construction, M.H, 2012. The business value of BIM in North America: multi-year trend analysis and user ratings (2007-2012), North America: McGraw-Hill Construction.

Construction, M.H, 2012. The business value of BIM in North America: multi-year trend analysis and user ratings (2007-2012)., s.l.: Smart Market Report.

Doumbouya, L., Gao, G. \& Guan, C., 2016. Adoption of the Building Information Modeling (BIM) for construction project effectiveness: The review of BIM benefits. American Journal of Civil Engineering and Architecture, 3(4), pp. 74-79.

Eadie, R. et al., 2013. BIM implementation throughout the UK construction project lifecycle: An analysis. Automation in Construction, Issue 36, pp. 145-151.

Eadie, R. et al., 2014. Building information modelling adoption: an analysis of the barriers to implementation. Journal of Engineering and Architecture, 2(1), pp. 77-101.

Eastman, . C., Teicholz, P., Sacks, . R. \& Liston, K., 2011. BIM Handbook, a Guide to Building Information Modelling. 2nd ed. Hoboken: John Wiley \& Sons, Inc.. 
Dec - 2019; Volume: 2 Issue: 2 page: 01-22

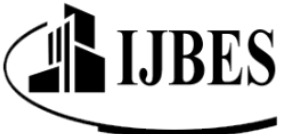

ISSN 2571-1075

Eastman, C., Teicholz, P., Sacks, R. \& Liston, K., 2008. BIM handbook: A guide to building information modeling for owners, managers, architects, engineers, contractors, and fabricators. 1st ed. Hoboken, NJ.: John Wiley and Sons.

Elbeltagi, E. \& Dawood, M., 2011. integrated visualized time control system for repetitive construction projects. Automation in Construction, 7(20), pp. 940-953.

Elhendawi, A., Smith, A. \& Elbeltagi, E., 2019. Methodology for BIM implementation in the Kingdom of Saudi Arabia. International Journal of BIM and Engineering Science , 2(1).

Elmualim, A. \& Gilder, J., 2014. BIM: innovation in design management, influence and challenges of implementation. Architectural Engineering and design management, 10((3-4)), pp. 183-199.

Farah, R., 2014. Building Information Modeling (BIM) Implementation in Saudi Arabia: Potentials and Barriers, KSA: The University of Salford School of the Built Environment;MSc dissertation.

Forbes, L. \& Ahmed, S., 2011. Modern construction: lean project delivery and integrated practices. s.l.:CRC Press.

Ganah, A. \& John, G., 2015. Integrating building information modeling and health and safety for onsite construction. Safety and health at work, 6(1), pp. 39-45.

Gerges, M, et al., 2017. An investigation into the implementation of Building Information Modeling in the Middle East. Journal of Information Technology in Construction (ITcon), 1(22), pp. 1-15.

Gerges, M., Ahiakwo, O., Jaeger, M. \& Asaad, A., 2016. Building Information Modeling and Its Application in the State of Kuwait. . World Academy of Science, Engineering and Technology, International Journal of Civil, Environmental, Structural, Construction and Architectural Engineering, 1(10), pp. 81-86.

Giang, D. \& Pheng, L., 2011. Role of construction in economic development: Review of key concepts in the past 40 years. Habitat International. Habitat International, 1(35), pp. 118-125.

Glick, S. \& Guggemos, A., 2009. IPD and BIM: Benefits and opportunities for regulatory agencies. Gainesville, Florida, In Proceedings of the 45th ASC National Conference, pp. 2-4.

Ham, N. et al., 2008. A study on application of bim (building information modeling) to pre-design in construction project.. s.l., In Convergence and Hybrid Information Technology, ICCIT'08.Third Internat.

Harrison, C. \& Thurnell, D., 2014. 5D BIM in a consulting quantity surveying environment.

Jernigan, F., 2014. Big BIM little BIM. 2nd ed. Maryland: 4Site Press publisher.

Karna, S., Junnonen, J. \& Sorvala, V., 2009. Modelling structure of customer satisfaction with construction. Journal of facilities management, 7(2), pp. 111-127.

Khalil, R., 2017. Value Engineering for Public Construction Projects In Qatar, Edinburgh : MSc Dissertation Edinburgh Napier University.

Latiffi, A., Mohd, S., Kasim, N. \& Fathi, M., 2013. Building information modeling (BIM) application in Malaysian construction industry. International Journal of Construction Engineering and Management, A(2), pp. 1-6.

Lee, S., Kim, . K. \& Yu, J., 2014. BIM and ontology-based approach for building cost estimation. Automation in Construction, Issue 41, pp. 96-105. 
Dec - 2019; Volume: 2 Issue: 2 page: 01-22

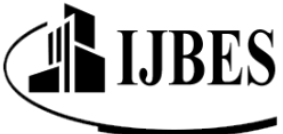

ISSN 2571-1075

Linderoth, H., 2010. Understanding adoption and use of BIM as the creation of actor networks. Automation in construction, 19(1), pp. 66-72.

Liu, R., Issa, R. \& Olbina, S., 2010. Factors influencing the adoption of building information modeling in the AEC Industry, In Proceedings of the International Conference on Computing in Civil and Building Engineering. Nottingham, Nottingham University Press, pp. (139-145.

Love, P. et al., 2014. A benefits realization management building information modeling framework for asset owners. Automation in construction, Volume 37, pp. 1-10.

Marzouk, M. et al., 2014. Modeling sustainable building materials in Saudi Arabia. In Computing in Civil and Building Engineering , pp. 1546-1553.

Matarneh, R. \& Hamed, S., 2017. Barriers to the Adoption of Building Information Modeling in the Jordanian Building Industry. Open Journal of Civil Engineering, 3(7), p. 325.

McCartney, C., 2010. Factors affecting the uptake of building information modelling (BIM) in the Auckland architecture, engineering \& construction (AEC) industry, New Zealand.: s.n.

McGraw-Hill, 2009. The business value of BIM: Getting Building Information Modeling in to Bottom Line, New York: Smart Market Report. New York: McGraw-Hill..

McGraw-Hill, 2012. The business value of BIM in North America: multi-year trend analysis and user ratings (2007-2012), New York: McGraw-Hill.: Smart Market Report.

Memon, A., Rahman, I., Memon, I. \& Azman, N., 2014. BIM in Malaysian construction industry: Status, advantages, barriers and strategies to enhance the implementation level. Research Journal of Applied Sciences, Engineering and Technology, 5(8), pp. 606-614.

Moreno, C., Olbina, S. \& Issa, R., 2013. School of building construction, USA.: university of Florida.

National Building Specification, 2014. NBS National BIM Report, UK: NBS.

Omar, H., 2015. Solutions for the UAE Architecture, Engineering, and Construction (AEC) industry to mandate Building Information Modeling (BIM), Dubai : (Doctoral dissertation, The British University in Dubai (BUiD))..

Omar, H. \& Dulaimi, M., 2015. Creating a sustainable future: Solutions for the construction waste in the Greater Cairo. Abu Dhabi, the first international conference of the CIB MENA research network, Smart, sustainable and healthy cities. Abu Dhabi University. 14-16 December 2014,, pp. 281-305.

Panuwatwanich, K. et al., 2013. Integrating building information modelling (BIM) into Engineering education: an exploratory study of industry perceptions using social network data..

Porwal, A. \& Hewage, K., 2013. Building Information Modeling (BIM) partnering framework for public construction projects. Automation in Construction, Volume 31, pp. 204-214.

Sabol, L., 2008. Building information modeling \& facility management. Dallas, Texas, USA.: IFMA World Workplace.

Saleh, M., 2015. Barriers and Driving Factors for Implementing Building Information Modelling (BIM) in Libya, Libya: (Master's thesis, Eastern Mediterranean University (EMU)-Doğu Akdeniz Üniversitesi (DAÜ)).. 
Dec - 2019; Volume: 2 Issue: 2 page: 01-22

ISSN 2571-1075

Salla, F., 2014. 15 advantages of using BIM. [Online] Available at: $\quad$ http://blog.visualarq.com/2014/03/12/15-advantages-of-using-bim/ [Accessed 14 December 2017].

Samuelson, O. \& Björk, B., 2013. Adoption processes for EDM, EDI and BIM technologies in the construction industry. Journal of Civil Engineering and Management, 19(1), pp. S172-S187..

Saunders, M., Lewis, P. \& Thornhill, A., 2012. Research Methods for Business Students: Lecturers' Guide.. s.l.:s.n.

Sebastian, R., 2011. Changing roles of the clients, architects and contractors through BIM. Engineering, Construction and Architectural Management, 18(2), pp. 176-187.

Shaban, M. \& Elhendawi, A., 2018. Building Information Modeling in Syria: Obstacles and Requirements for Implementation. International Journal of BIM and Engineering Science, 1(1).

Succar, B., Sher, W. \& Williams, A., 2013. An integrated approach to BIM competency assessment, acquisition and application. Automation in construction, Volume 35, pp. pp.174-189.

Volk, R., Stengel, J. \& Schultmann, F., 2014. Building Information Modeling (BIM) for existing buildings-Literature review and future needs. Automation in construction, Volume 38, pp. 109-127..

Wang, J., Wang, X., Shou, W. \& Bo Xu, , 2014. Integrating BIM and augmented reality for interactive architectural visualisation. Construction Innovation, 14(4), pp. 453-476.

Zewein, W., 2017. Assessment of using BIM with Lean Construction for effectiveness achievement of construction projects in Qatar, Edinburgh: MSc Dissertation Edinburgh Napier University. 